\title{
Adverse occupational events and their impact on the centrality of work: \\ A longitudinal study
}

\author{
Moshe Sharabi $^{{ }^{*}}$, Ola Abu-Hasan Nabwani ${ }^{2}$, Tal Shahor ${ }^{3}$, Javier Simonovich ${ }^{4}$
}

${ }^{1 *}$ Department of Sociology and Anthropology, Yezreel Valley Academic College, Israel; ${ }^{2}$ School of social sciences and humanities, Kinneret Academic College, Tzemach, Israel; ${ }^{3}$ Department of Human Services, Yezreel Valley Academic College, Emek Yezreel, Israel; ${ }^{4}$ Department of Economics, Yezreel Valley Academic College, Emek Yezreel, Israel. Email: ${ }^{1 *}$ moshes@yvc.ac.il, ${ }^{2}$ ola.nabwani@mail.huji.ac.il, ${ }^{3}$ tals@yvc.ac.il, ${ }^{4}$ javiers@yvc.ac.il

\section{Keywords}

Work Centrality, Occupational Events, Life Course Effect, Longitudinal Research, Israel.

\section{Article History}

Received on $19^{\text {th }}$ July 2021

Accepted on $31^{\text {st }}$ August 2021

Published on $8^{\text {th }}$ September 2021

\section{Cite this article}

Sharabi, M., Abu-Hasan Nabwani, O., Shahor, T., \& Simonovich, J. (2021). Adverse occupational events and their impact on the centrality of work: A longitudinal study. Humanities \& Social Sciences Reviews, 9(5), 15-22.

https://doi.org/10.18510/hssr.2021.953

\section{Copyright @ Author}

Publishing License

This work is licensed under a Creative Commons Attribution-Share Alike 4.0 International License

\section{(c) (1) (2)}

\section{Abstract}

Purpose: The purpose of this study is to examine the changes in work centrality of individuals who experienced meaningful adverse occupational events (dismissal from the workplace, prolonged unemployment, and retirement), as compared to employees who did not experience such events over 12 years.

Methodology: By implementing a fixed-sample panel /longitudinal research,12 years after conducting the Meaning of Work questioner, 411 individuals were located and re-conducted. The respondents were asked about life and work events they had experienced between the first and second time. The data was analysed by regular and multivariate analysis of variance.

Main Findings: The work centrality of individuals who experienced prolonged unemployment did not change, while it increased among those who did not experience these events. Experiencing dismissal from work increased work centrality. Unexpectedly, work centrality continues to increase among individuals after retirement.

Applications: There are several suggestions for the social and welfare and policymakers regarding adverse occupational events and the impact these policies may have on the magnitude of these events on work centrality.

Novelty/Originality: This is a unique longitudinal study over twelve years, that compared the change in work centrality among individuals who did and did not experience adverse occupational events.

\section{INTRODUCTION}

Over time, people experience expected and unexpected life and occupational events. These positive (e.g., marriage, childbirth, promotion to managerial position) and adverse (e.g., divorcee, unemployment) meaningful events can affect people's affective and cognitive well-being, mental and physical health, values, and beliefs (Bakker, Du \& Derks, 2019; Hobson, Delunas \& Kesic, 2001; Luhmann, Hofmann, Eid \& Lucas, 2012; Sharabi \& Harpaz, 2010). Experiencing major events requires individuals to make a significant readjustment and can have both short-term and long-term effects on their values and work centrality (Luhmann, et al., 2012; Sharabi \& Harpaz, 2010). To examine the effects of occupational events on work centrality, there is a need for a longitudinal study over several years. As far as we know, there is no study about the relationships between meaningful occupational events and work centrality and their causality aside from ours.

The Meaning of Work International Research Team (MOW, 1987) defined "work centrality" as the degree of general importance that work has in one's life at any given time Work is an essential part of human existence and plays a fundamental role in the lives of individuals. Research has indicated that people consider work and work outcomes to be an essential aspect of their lives, as well as an important means of meeting several needs. Essential to the above are the economic or instrumental purposes served by work, allowing people to secure their basic sustenance and satisfy their material needs. However, above and beyond the material benefits of work, an interest in and commitment to work has also been part of human nature and human needs. Finally, work has also been associated with socio-psychological or intrinsic factors and it emphasizes the contribution of work to an individual's identity, social relationships, self-esteem, status, and sense of accomplishment (Bakker, Du \& Derks, 2019; MOW, 1987; Rosso, Dekas \& Wrzesniewski, 2010; Sharabi \& Harpaz, 2019). From various studies, we can conclude that the importance of work (and that of home/ family) is of higher importance relative to other areas of life in different countries around the world, that is despite the cultural and social differences (Sharabi \& Harpaz, 2007; Kuchinke et al., 2011; Meda, 2017).

Furthermore, there is a positive correlation between work centrality and important organizational variables, such as job satisfaction, participation in decision-making, and willingness to work longer hours, than employees who have low work centrality. Additionally, there is a negative relationship between work centrality, absenteeism, and turnover (Bakker, Du \& Derks, 2019; Rosso et al., 2010; Sharabi \& Harpaz, 2019; Snir \& Harpaz, 2002). 


\section{The rationale of the study}

Varied studies found that employee's high work centrality, related to high job performance, work involvement, motivation,

organization commitment etc. (Rosso et al., 2010; Sharabi \& Harpaz, 2019; Diefendorff et al., 2002). Therefore, employee's work centrality has an impact on organizational performance and success. Whether occupational events such as dismissal from the workplace, prolonged unemployment, and retirement, increase or decrease the centrality of work among individuals (and as a result increase their involvement, motivation, performance, and outcomes) over time. Furthermore, to conclude about the causal relations between work centrality and occupational events, there is a need to do follow-up research on the same individuals.

\section{The purpose of the study}

The purpose of this research is to examine the impact of adverse occupational events (such as dismissal from the workplace, retirement, etc.) on an individual's work centrality. Specifically, we explore whether changes have occurred in the work centrality of individuals who experience meaningful occupational events, as compared to employees who do not experience such events over 12 years. To the best of our knowledge, there is no longitudinal research examining the relationships between different occupational events and work centrality and its causality

\section{LITERATURE REVIEW}

\section{Life-course and life \occupational events}

In the social sciences, there is a serious consideration as to how human maturation affects people's health, behaviour, values, and norms. Moreover, there is a wide range of terminologies in use, such as "Life Course Event", "Life span Event", or "Life Cycle Events" which refer to the periodicity of a person's life, from birth to death, during which a person undergoes different stages such as childhood, maturity, career development, family life, economic stability, etc. (see: Baxter et al., 2015; Elder, 1998; Shanahan, Mortimer \& Johnson, 2016; O’Rand \& Krecker, 1990; Rank \& Hirschl, 2002; Super, 1990). Through these events, one's personality, preferences, and values change as that individual matures. The importance and centrality of work increase parallel to changes in the prominence of other life roles (Sharabi \& Harpaz, 2010; Sharabi, Polin \& Yanay, 2019; Super, 1990).

Several scholars claim that these models represent a sequence of developmental changes that an individual undergoes, while in actuality, unpredictable events which disrupt this course of events occur in one's (e.g., O'Rand \& Krecker, 1990; Duncan, 1988; Rank \& Hirschl, 2002; Shanahan et al., 2016). For example, divorce or divorce followed by remarriage, changes the course of one's life, produces a late-life founding of a new family, and have an impact on an individual's economic stability.

It is important to emphasize that a country and its decisions affect one's life course events and how dramatic they may be. Mayer \& Schoepflin (1989) discuss the impact of a country on an individual's life and life events. They believe that social policies and legislation regarding subjects such as the age at which compulsory school studies begin, the prohibition of child labour, the minimum age for marriage, the retirement age, etc., have an apparent effect on an individual's life. The social policy that varies between countries also affects the many life events of the individual and how dramatic they may be, following the level of involvement and support given by the welfare system (Baxter et al., 2015; Rank \& Hirschl, 2002). Unemployment benefits, income security, health insurance, child benefits, career retraining finance, etc., can ease and even prevent an individual from specific crises that may result from occupational and life events such as childbirth and expansion of the family, divorce, job dismissal, prolonged unemployment, disease, etc.

The occupational events which are described in our research, are considered by the psychological literature as stress factors (stressors). These stressors are defined as traumatic events or significant changes in one's life (Luhmann et al., 2012; Bromet et al., 1988; Hobson et al., 2004; Shanahan et al., 2016). These stressors can affect a person's physical and mental health (Luhmann et al., 2012) and the traumatic ones especially, can influence people's world view, their approach to various subjects, their values, and their behaviour (Bromet et al., 1988; Luhmann et al., 2012).

\section{Adverse Occupational Events and work centrality}

Amongst adverse occupational events that we include in our study: job dismissal, prolonged unemployment, and retirement. As we have stated, these occupational events, as stressors, can influence the different values of an individual. There are few studies about the effect of occupational events on work values and work centrality. Next are the findings of these studies.

\section{Job dismissal, unemployment, and work centrality}

Job dismissal and resulting unemployment are counted as especially traumatic work events. It has been found that job tenure and the feeling of job security contribute to a rise in work centrality (Dubin \& Chamoux, 1977; Noon, et al., 2013). Dismissal from the workplace can be seen as an extreme case of a lack of job security, which results in a period of unemployment for the individual. Dismissal from the workplace and unemployment were found to influence an individual's confidence and sense of individuality, work ethic, and especially the increase in the importance of financial income in instances such as these (Isaksson et al., 2004; Noon, et al., 2013; Janlert, et al., 2015). 
Rothman (1987) states four negative aspects regarding an individual, which can result from prolonged unemployment: (a) economic harm following the lack of a steady income, (b) reduction in social relationships resulting from the lack of contact with colleagues, and a lack of money to finance social entertainment, (c) decreased self-esteem and self-respect as a result of humiliation that the individual has experienced while searching for work, and (d) damaging effects on mental and physical health as a result of the psychological pressures arising from the situation.; Indeed, prolonged unemployment is correlated with a deterioration in health and risky health behaviour (Janlert, et al., 2015) as well as a larger negative psychological effect, especially on those who are highly invested in their work (Janlert, et al., 2015; Isaksson et al., 2004). It was found that dismissal from the workplace followed by a period of unemployment, causes a decrease in work centrality. Furthermore, work centrality among the unemployed is lower in comparison to people who are employed in various jobs, similar to that of part-time workers (Harpaz, 1990; MOW, 1987). As the period of unemployment extends, the tendency of the unemployed to search for a new job declines (Janlert, et al., 2015; Sharabi \& Simonovich, 2017), which indicates an increasing readiness to accept the situation and a lack of active working life. In addition, it was found that in countries where there is a prolonged period of high unemployment rates (e.g., Germany), there is a steady decrease in work centrality, and it is relatively lower compared to other countries (Sharabi \& Harpaz, 2007).

In conclusion, job loss and unemployment in the short term increase the centrality of work, since it dramatically changes an individual's routine and way of life in addition to harming them physically, psychologically, and financially (Noon, et al., 2013; Janlert, et al., 2015). Long-term unemployment decreases the centrality of work, since individuals get used to being unemployed, thus lowering expectations regarding finding a job. At the same time, they are developing a leisure activity to fill their free time (Sharabi \& Harpaz, 2007; Sharabi \& Simonovich, 2017; Noon, et al., 2013). Based on the review, we offer the following hypotheses:

Hypothesis 1: dismissal from the workplace/ job loss will contribute to an increase in the work centrality of an individual in comparison to those who have not experienced such an event.

Hypothesis 2: prolonged unemployment will contribute to a decrease in the work centrality of an individual, in comparison to those who have not experienced such an event.

\section{Retirement and work centrality}

Similar to unemployment, retirement may have negative psychological and physiological indications because of the detachment from an intensive working life and the immediate transition to an extra free time where leisure becomes central in life (Dosman et al., 2006; Robinson, Coberly \& Paul, 1985; Froidevaux \& Hirschi, 2015). It was found that amidst adults nearing retirement age, in Japan and the USA, there was a decrease in work centrality and a decline in the readiness to work after entering retirement age (England \& Misumi, 1986). This finding can be explained via Cummings \& Henry's (1961) "Disengagement Theory", which stated that workers approaching retirement prepare themselves mentally and try to find different life interests in which to invest their time. As a result, the work centrality among this population will decrease (Misumi \& Yamori, 1991; Dosman et al., 2006; Froidevaux \& Hirschi, 2015). These findings coincide with a lowered willingness to work in the absence of an economic constraint among older people (Mannheim \& Rein, 1981; Sharabi \& Harpaz, 2019). Furthermore, people who are actual retirees grants lower importance to work, in comparison to employed groups, while granting higher importance to family and community domains (Harpaz, 1990; MOW, 1987). Based on the above, the following hypothesis was formulated:

Hypothesis 3: event of retirement will contribute to a decrease in the work centrality of an individual in comparison to those who have not experienced this event.

\section{METHOD}

\section{Samples and Data Collection}

A longitudinal study about the "Meaning of Work" was conducted in 1981, 1993, and again in 2005 among Israeli employees. From 973 individuals of the original samples, we succeeded in locating and interviewing only 411 after 12 years from the first interview. This final sample included 158 women and 249 men; their mean age was 52.4 years. Regards respondents' educational level, 19.6 percent finished elementary school, 38.5 percent finished secondary school, 20.8 percent had post-secondary education and 21.1 percent had an academic degree. By implementing a fixed-sample panel /longitudinal research, we examine the same respondents in the long term. This method enabled us to study the impact of occupational events on work centrality over the years and the causal relationship between them.

\section{Measures}

In addition to the question about their work centrality, the re-interviewed respondents were asked if they experienced adverse occupational events between the first and second time.

Work centrality was measured by the question: "What is the importance of work and its meaning in your life?" and the scale was from 1 to 7 (one of the least / most important things in my life) (see MOW, 1987 questionnaire). This measurement has been implemented in various countries for almost four decades and the findings over time show that this measurement had high reliability and validity. 
Occupational Events - The impact of meaningful adverse occupational events on the work centrality of the sample was measured by the question: "Please stipulate which central events or changes (that are especially meaningful or important) taking place in your occupational life in the last decade, had a significant effect on how you relate to your work (attitude to work, motivation, values, the effort you put into work, etc.)."

Respondents who experienced occupational events such as dismissal from work, prolonged unemployment, and retirement were asked to rate the effect from 1 (no effect) to 5 (significant effect). We only addressed some of the occupational events, those that were experienced by a high number of individuals, and which have a theoretical basis regards their effect on work centrality.

\section{Analysis}

Since we had to examine the causality of the relationship between occupational events and the centrality work, in addition to the maturation effect among the sample, we used some statistical methods. The changes in the centrality of work among those who did or did not experience each of the occupational events were measured by the residuals $(\Delta)$ between T1 and T2 (using t-test). At T1, we compared the centrality of work among those who would and would not experience each of the occupational events, and at $\mathrm{T} 2$, the work centrality means of those who did or did not experience each of the occupational events (using ANOVA).

The respondent's maturation in 12 years since the beginning of the study was measured by the interaction between the event and the maturation of the respondent in addition to the effect of the event (using MANOVA).

\section{FINDINGS}

Table 1 presents the types of occupational events and their occurrence and changes in work centrality of the sample during the 12-years. The main findings from table 1 are represented by figures that portray the differences in work centrality between those who have or have not experienced occupational events.

Table 1: Occupational events and work centrality among a research group between T1 and T2

\begin{tabular}{|c|c|c|c|c|c|c|c|c|}
\hline & $\begin{array}{l}\text { Will } \\
\text { Experience the event? }\end{array}$ & $\mathbf{n}$ & $\begin{array}{l}\text { T1 } \\
\text { Means }\end{array}$ & $t$-test ${ }^{\mathrm{a}}$ & $\begin{array}{l}\text { T2 } \\
\text { Means }\end{array}$ & $t$-test ${ }^{\mathrm{b}}$ & $\begin{array}{l}\text { t-test } \\
\text { to } \Delta^{\mathrm{c}}\end{array}$ & $\begin{array}{l}F \\
\text { test }^{\text {d }}\end{array}$ \\
\hline \multirow{2}{*}{$\begin{array}{l}\text { Have been dismissed } \\
\text { from workplace }\end{array}$} & no & \multirow{2}{*}{$\begin{array}{l}308 \\
54\end{array}$} & 5.56 & \multirow[t]{2}{*}{55.} & 5.72 & -1.12 & ${ }^{ \pm} 1.78$ & 1.52 \\
\hline & yes & & 5.43 & & 5.93 & & $1.98 *$ & \\
\hline \multirow{2}{*}{$\begin{array}{l}\text { Had prolonged } \\
\text { unemployment }\end{array}$} & no & \multirow{2}{*}{$\begin{array}{l}308 \\
47\end{array}$} & 5.54 & \multirow[t]{2}{*}{-.34} & 5.76 & .05 & $2.39 *$ & .12 \\
\hline & yes & & 5.62 & & 5.64 & & .03 & \\
\hline \multirow[t]{2}{*}{ Retiring } & no & \multirow{2}{*}{$\begin{array}{l}275 \\
89\end{array}$} & 5.46 & \multirow[t]{2}{*}{$-2.30 *$} & 5.63 & $2.96 * *$ & ${ }^{ \pm} 1.64$ & .37 \\
\hline & yes & & 5.83 & & 6.12 & & ${ }^{ \pm} 1.65$ & \\
\hline
\end{tabular}

${ }^{\text {a }}$ Work centrality differences at $\mathrm{T} 1$ between those who will experience each occupational event and those who will not $(t$-test).

${ }^{\mathbf{b}}$ Work centrality differences at T2 between those who did experience each occupational event and those who did not ( $t$ test).

${ }^{\mathbf{c}}$ Work centrality differences between $\mathrm{T} 1$ and $\mathrm{T} 2$ among those who did experience each occupational event and those who did not ( $t$-test for residuals).

${ }^{\mathbf{d}}$ Interaction of maturation effect and the effect of the event (mix design ANOVA between and within the respondents).

${ }^{ \pm} \mathrm{P}<.10 * * \mathrm{P}<.05 \quad * * \mathrm{P}<.01 \quad * * * \mathrm{P}<.001$

Among those who experienced dismissal from work, the event led to a significant increase in their work centrality (from 5.43 before dismissal to 5.93 after, $\mathrm{P}<.05$ ), confirming Hypothesis 1. As presented in Figure 1, while in T1, they had lower work centrality compared to those who would not later experience dismissal, after they experienced the event, their work centrality is higher than their counterparts.

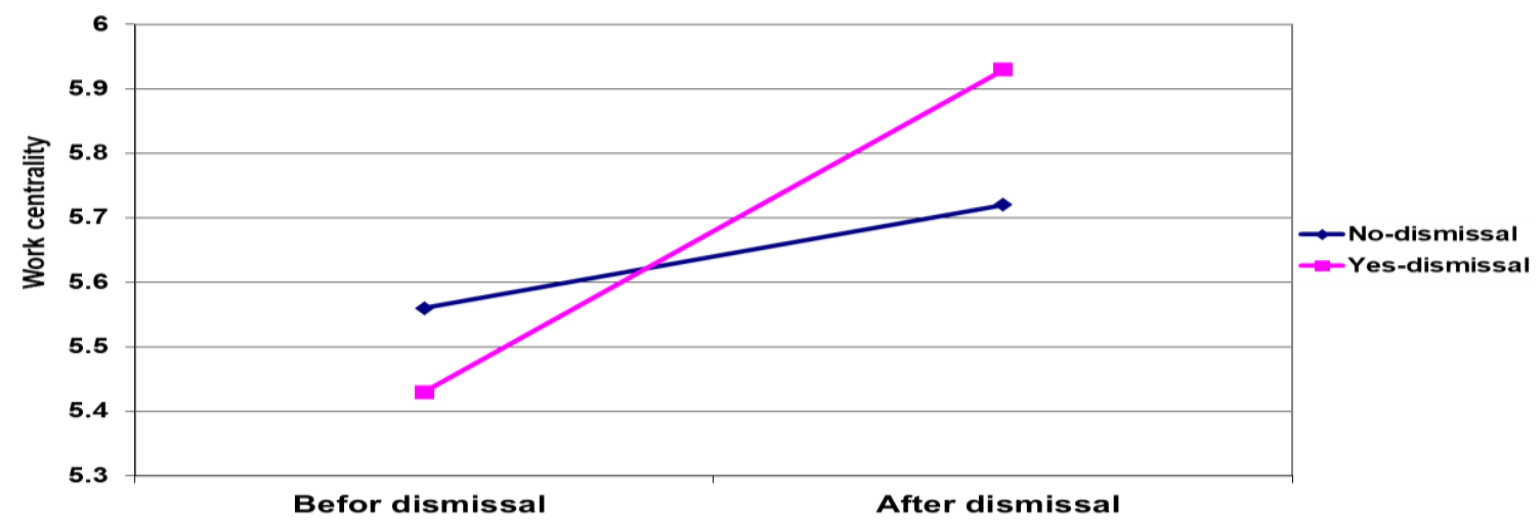

Figure 1: Work centrality among employees who will be dismissed among those who do not 
As presented in Figure 2, prolonged periods of unemployment did not cause a decline in work centrality, instead, it was stable. However, there is a significant increase in work centrality (from 5.54 to $5.76, \mathrm{P}<.05$ ) among those who did not experience prolonged unemployment.

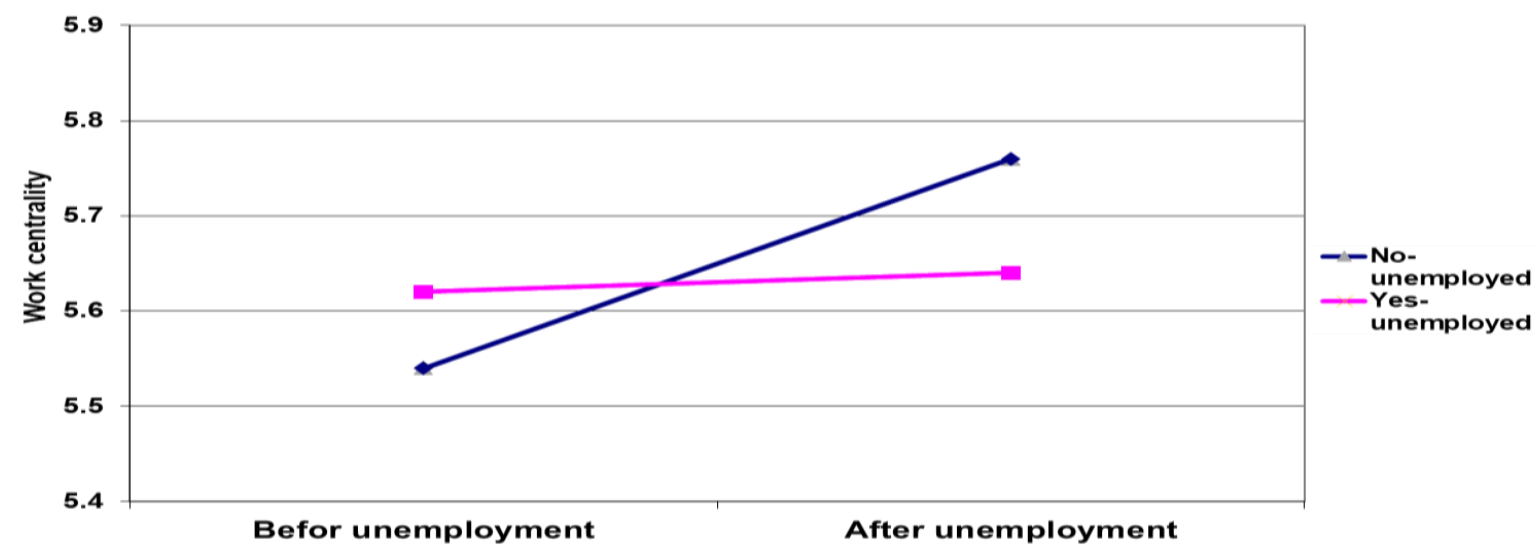

Figure 2: Work centrality among those who will not experience/experienced prolonged unemployment

Those who are going to retire had significantly higher work centrality than those who would continue working (5.83 compared to 5.46 respectively, $\mathrm{P}<.05)$. Retirement does not contribute to a decline in work centrality, which instead increases after retirement (from 5.83 pre-retirement to 6.12 post-retirement, $\mathrm{P}<.10$ ), as can be seen in Figure 3 . The above findings did not match our hypotheses 2 and 3, since unemployment and retirement did not contribute to a decrease in individuals' work centrality compared to those who did not experience such events.

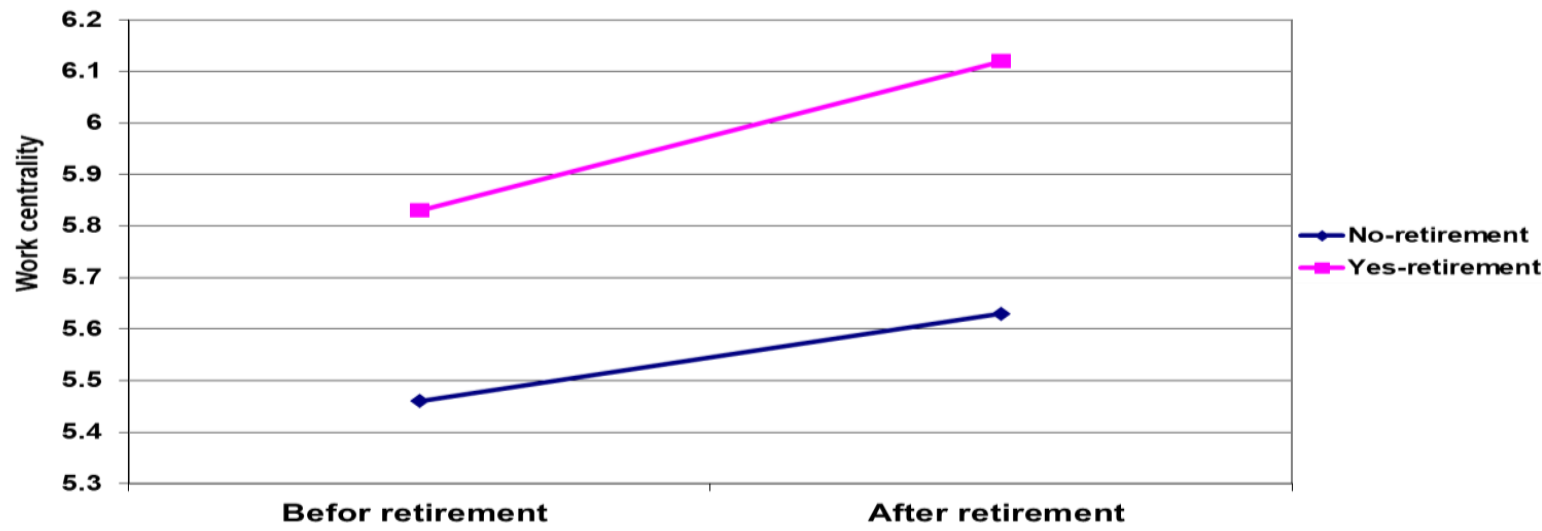

Figure 3: Work centrality among employees who will retire/retired and among those who do not

\section{DISCUSSION}

Overall, the centrality of Work among individuals is increasing with ageing (Kuchinke et al., 2011; MOW, 1987; Sharabi \& Harpaz, 2007) and there was an expected increase among some of the participants. However, other participants showed stability in their centrality of work or a decrease over time.

Dismissal from work seems to be a shocking event. Those who lost their jobs showed a dramatic increase in work centrality compared to a slight increase among those who did not experience it. This job loss changes individuals' routines and way of life dramatically as well as harms them physically, psychologically, and financially (Noon et al., 2013; Janlert et al, 2015). It leads them to bestow more importance to work, as we found. Moreover, individuals who experienced dismissal over time had lower work centrality from the outset than those who did not. It appears that an individual's low work centrality could be a predictor of one's future dismissal.

A dismissal event can lead to periods of prolonged unemployment, but unlike dismissal, work centrality does not change among those who experience prolonged unemployment. However, during this period, there was a significant increase in the centrality of work, among those who did not experience prolonged unemployment. The findings do not support our assumption that prolonged unemployment would contribute to a decline in work centrality. However, since the work centrality of the research population increased with age, the stability of work centrality among those who experienced prolonged unemployment reflects the negative effect of the event on work centrality. There are several main explanations for this.: a) individuals are becoming used to being unemployed, thus lowering their expectations of finding a job and are investing more in family and leisure domains at the expense of work domain (Sharabi \& Harpaz, 2007; Sharabi \& Simonovich, 2017; Noon, et al., 2013); b) resulting in a decreased self-esteem and self-respect due to the humiliation that the individual has experienced while searching for a job (Rothman 1987; Janlert, et al., 2015); and c) 
lastly, with ageing, it becomes harder to find a suitable job that would enhance interest in work-life (Sharabi \& Simonovich, 2017).

In this case, social and economic policies could moderate the negative impact of these events on the individual (see Baxter et al., 2015; Rank \& Hirschl, 2002). It can be assumed that these policies, as expressed in the Israeli welfare system (income security, unemployment benefits, etc.), minimized the level of trauma caused by dismissal from the workplace or a prolonged period of unemployment.

In practice, prolonged unemployment, regardless of the welfare policies as described, contributes to a worsening economic situation due to the lack of a steady income, and as a result, getting into debt (see O'Rand \& Krecker, 1990; Rothman, 1987; Shanahan et al., 2016). Beyond the fact that dismissal from work and unemployment contribute to changes of values in the importance of work, they also contribute to a rise in the matter of financial income and job security (Sharabi \& Harpaz, 2016).

Unexpectedly, the work centrality of those supposed to retire during the study period is significantly higher than those who would continue working. The findings refute the Disengagement Theory, which maintains that an employee's work centrality will decrease before approaching retirement since they are preparing themselves mentally to leave and are trying to find different life interests in which invest their time (Cummings \& Henry, 1961; Mannheim \& Rein, 1981; Froidevaux \& Hirschi, 2015). Furthermore, work centrality continues to rise even after retirement, which may reflect the psychological crises among retirees since work becomes more critical, still, they cannot turn this growing need into action. Eckerdt (1986) found that work ethics and work values are not forgotten after the individual retires. Retirees try to continue occupying themselves with activities to replace the time that had previously been spent on work, thus maintaining their lifestyle before retirement. Many of them would not find alternative meaning in life after retirement (Froidevaux \& Hirschi, 2015) and would attempt to find alternative activities, including temporary jobs and volunteering (Dosman et al., 2006)

Retirement immediately cut varied emotional needs such as interpersonal relationships with co-workers, self-fulfilment, status, need for identification with working, job, organization, etc. (Eckerdt, 1986; Froidevaux \& Hirschi, 2015; Robinson, et al. 1985). It seems that the inability to fulfil these needs increases the importance of work among retirees, whereas in reality, other life domains, especially leisure and family, fill the gap between what one wants and what one has (Dosman et al., 2006; Eckerdt, 1986; Froidevaux \& Hirschi, 2015; Super, 1990).

In this case, as well, public policies can mitigate the retirement crisis by providing alternatives to work through various projects of community service, which can contribute to both the community and the retired, so that both sides benefit. At the same time, there is a need to develop leisure activities and culture at the community level to provide activities to enrich the daily routine of retired people. In conclusion, there is a need to provide meaning in life beyond work (see suggestion by Froidevaux \& Hirschi, 2015)

It should be emphasized that when comparing countries regarding the effects of various occupational and life events on an individual's work centrality, the social policies in every country should also be taken into consideration. These governmental social policies may moderate the influence of occupational and life events that the citizens undergo following the degree of involvement and support that the social welfare system offers (Mayer \& Schoepflin, 1989; Baxter et al., 2015; Rank \& Hirschl, 2002; Shanahan et al., 2016).

In conclusion, the maturing of the subjects contributes to changes in work values. As mentioned at the beginning of the discussion, work centrality increases with age. When analysing the findings, we investigated the impact of adverse occupational events on work centrality among those who have and those who have not experienced them, while measuring the interaction with the maturation of the sample. Furthermore, there is a reference to welfare and social policies regarding adverse occupational events, and the impact these policies may have on the magnitude of these events on work centrality.

\section{LIMITATIONS AND STUDY FORWARD}

This study has several limitations. There is a difficulty in attempting to differentiate between occupational events the respondents experienced, to examine their relationship with work centrality, since indeed some of the respondents had experienced several events during the period of this research. Some of the events result from other events (e.g., dismissal leads to unemployment and sometimes prolonged unemployment). Furthermore, the respondents were required to note the occupational events they underwent in retrospect, and the answers do not contain information as to when and how many times each event occurred (such as dismissal from the workplace, prolonged unemployment, and more) during twelve years.

Regarding future longitudinal studies examining the relationships between occupational events and work centrality, it is recommended to perform them several times over a shorter period (about every one to two years). In that way, it would be possible to address occupational events that the respondents experienced between each period and would allow a more thorough understanding of the causal relationships between these events and work centrality. This way, it would be possible to examine the influence of a single event, or the combined influence of several related occupational events, on work centrality during an individual's life. 


\section{AUTHOR'S CONTRIBUTION}

The first author proposed the concept, supervised the project and the data analysis. The second author wrote part of the literature review and the discussion. The third and the fourth author were engaged in the revision, compiling manuscripts and editing.

\section{REFERENCES}

1. Bakker, A. B., Du, D., \& Derks, D. (2019). Major life events in family life, work engagement, and performance: A test of the work-home resources model. International Journal of Stress Management, 26(3), 238. https://doi.org/10.1037/str0000108

2. Baxter, J., Buchler, S., Perales, F., \& Western, M. (2015). A life-changing event: First births and men's and women's attitudes to mothering and gender divisions of Labour. Social Forces, 93(3), 989-1014. https://doi.org/10.1093/sf/sou103.

3. Bromet, E.J., Dew, M.A. Parkinson, D.K. \& Schulberg, H.C. (1988). Predictive Effects of Occupational and Marital Stress on the Mental Health of a Male Workforce. Journal of Organizational Behaviour, 9, 1-13. https://doi.org/10.1002/job.4030090102

4. Cummings, E., \& Henry, W. E. (1961). Growing old: The Process of Disengagement. New York, NY: Basic Books.

5. Diefendorff, J. M., Brown, D. J., Kamin, A. M., \& Lord, R. G. (2002). Examining the roles of job involvement and work centrality in predicting organizational citizenship behaviours and job performance. Journal of organizational behaviour, 23(1), 93-108. https://doi.org/10.1002/job.123

6. Dosman, D., Fast, J., Chapman, S. A. \& Keating, N. (2006). Retirement and Productive Activity in Later Life. Journal of Family and Economic Issues. 27 (3) 401-419. https://doi.org/10.1007/s10834-006-9022-y

7. Dubin, R. \& Chamoux, J.E. (1977). Central Life Interests and Job Satisfaction. Organizational Behaviour and Human Performance, 18, 366-377. https://doi.org/10.1016/0030-5073(77)90036-8

8. Duncan, G.J. (1988). The Volatility of Family Income over the Life Course. In P.B. Baltes, D.L. Featherman, R.M. Lerner (Eds.) Life-Span Development and Behaviour. Hillsdale, NJ: Erlbaum, 317-358.

9. Eckerdt, D. J. (1986), The Busy Ethic: Moral Continuity Between Work and Retirement. The Gerontological Society of America, 26 (3) 239-244. https://doi.org/10.1093/geront/26.3.239.

10. Elder, G. H, Jr. (1998). The life course and human development. In R. M. Lerner (Ed.), Handbook of child psychology (Vol. 1, pp. 939-991). New York: Wiley.

11. England, G. W. \& Misumi, J. (1986). Work Centrality in Japan and the USA. Journal of Cross-Cultural Psychology, 17, 399-416. https://doi.org/10.1177/0022002186017004002

12. Froidevaux, A., \& Hirschi, A. (2015). Managing the transition to retirement: From meaningful work to meaning in life at retirement. In De Vos, A., \& Van der Heijden, B. I. (Eds.). Handbook of research on Sustainable Careers (pp. 350-363). Cheltenham Glos, UK: Edward Elgar Publishing.

13. Harpaz, I. (1990), The Meaning of Work in Israel, It's Nature and Consequences, New York: Praeger.

14. Hobson, C. J., Delunas, L., \& Kesic, D. (2001). Compelling evidence of the need for corporate work/life balance initiatives: results from a national survey of stressful life-events. Journal of employment counselling, 38(1), 38-44. https://doi.org/10.1002/j.2161-1920.2001.tb00491.x

15. Hobson, C. J., Kesic, D., Rosetti, D., Delunas, L. \& Hobson, N. G. (2004). Motivating Employee Commitment with Empathy and Support during Stressful Life Events, International Journal of Management, 21 (3) 332-337.

16. Isaksson, K., Johansson, G., Bellaagh, K. \& Sjoberg, A. (2004). Work values among the unemployed: Changes over time and some gender differences, Scandinavian Journal of Psychology, 45 (3) 207-214. https://doi.org/10.1111/j.1467-9450.2004.00396.x

17. Janlert, U., Winefield, A. H., \& Hammarström, A. (2015). Length of unemployment and health-related outcomes: a life-course analysis. The European Journal of Public Health, 25(4), 662-667. https://doi.org/10.1093/eurpub/cku186

18. Kuchinke, K. P., Ardichvili, A., Borchert, M., Cornachione Jr, E. B., Cseh, M., Kang, H. S., ... \& Zav'jalova, E. (2011). Work meaning among mid-level professional employees: A study of the importance of work centrality and extrinsic and intrinsic work goals in eight countries. Asia Pacific Journal of Human Resources, 49(3), 264284. https://doi.org/10.1177/1038411111413217.

19. Luhmann, M., Hofmann, W., Eid, M., \& Lucas, R. E. (2012). Subjective well-being and adaptation to life events: a meta-analysis. Journal of personality and social psychology, 102(3), 592. https://doi.org/10.1037/a0025948

20. Mannheim, B. \& Rein, J. (1981). Work Centrality and Different Age Groups and Wish to Discontinue Work. International Journal of Aging and Human Development, 13, 221-232. https://doi.org/10.2190/T26A-3P8P7YLQ-7K7R

21. Mayer, K.U. \& Schoepflin, U. (1989). The State and the Life Course. Annual Review of Sociology, 15: $187-209$. https://doi.org/10.1146/annurev.so.15.080189.001155

22. Meda, D. (2017). The future of work: the meaning and value of work in Europe. ILO Research Paper No. 18, Geneva: ILO.

23. Misumi, J., \& Yamori, K. (1991). Values and beyond: Training for a higher work centrality in Japan. The European Work and Organizational Psychologist, 1(2-3), 135-145. https://doi.org/10.1080/09602009108408518 
24. MOW - International Research Team, (1987). The Meaning of Working, London: Academic Press.

25. Noon, M., Blyton, P., \& Morrell, K. (2013). The realities of work: Experiencing work and employment in contemporary society. Palgrave Macmillan, New York.

26. O'Rand, M.A. \& Krecker, L.M. (1990). Concepts of the Life Cycle: Their History, Meanings, and Uses in the Social Sciences. Annual Review of Sociology, 16, 241-262. https://doi.org/10.1146/annurev.so.16.080190.001325

27. Rank, M. R., \& Hirschl, T. A. (2002). Welfare use as a life-course event: Toward a new understanding of the US safety net. Social Work, 47(3), 237-248. https://doi.org/10.1093/sw/47.3.237

28. Robinson, P. K., Coberly, S. \& Poul, C. E. (1985). Work and Retirement. In R. H. Binstock \& E. Shanas (Eds.) Handbook of ageing and the Social Sciences, N.Y.; Van Nostrand Reinhold Co.

29. Rosso, B. D., Dekas, K. H., \& Wrzesniewski, A. (2010). On the meaning of work: A theoretical integration and review. Research in Organizational Behaviour, 30, 91-127. https://doi.org/10.1016/j.riob.2010.09.001

30. Rothman, R. A. (1987). Working: sociological Perspective. Englewood Cliffs, N.J.: Prentiss Hall.

31. Shanahan, M. J., Mortimer, J. T., \& Johnson, M. K. (Eds.) (2016). Handbook of the life course, Switzerland: Springer.

32. Sharabi, M. \& Harpaz, I. (2007). Changes in Work Centrality and Other Life Areas in Israel: A Longitudinal Study. Journal of Human Values, 13 (2), 95-106. https://doi.org/10.1177/097168580701300203

33. Sharabi, M., \& Harpaz, I. (2010). Improving employees' work centrality improves organizational performance: work events and work centrality relationships. Human Resource Development International, 13(4), 379-392. https://doi.org/10.1080/13678868.2010.501960

34. Sharabi, M. \& Harpaz, I. (2016). Impact of Generational Differences on Work Values in the Israeli Context, in M. Sharabi (Ed.) Generational Differences in Work Values and Work Ethic: An International Perspective (pp. 19-41). Hauppauge, N. Y.: Nova Science Publishers.

35. Sharabi, M. \& Harpaz, I. (2019). To Work or Not to Work: Variables Affecting Non-financial Employment Commitment over time, International Labour Review, 158 (2), 393-417. https://doi.org/10.1111/ilr.12141

36. Sharabi, M. Polin, B. \& Yanay, G. (2019). The Effect of Social and Economic Transitions on the Meaning of Work: Cross-Sectional Study, Employee Relations, 41(4), 724-739. https://doi.org/10.1108/ER-04-2018-0111

37. Sharabi, M., \& Simonovich, J. (2017). Weak ties for a weak population: expanding personal social networks among the unemployed to increase job-seeking success. Journal of employment counselling, 54(1), 12-22. https://doi.org/10.1002/joec. 12047

38. Snir, R. \& Harpaz, I. (2002). Work-leisure relations: Leisure orientation and the meaning of work, Journal of Leisure Research, 34 (2), 178-203. https://doi.org/10.1080/00222216.2002.11949968

39. Super, D. E. (1990). A life-span, life-space approach to career development. In: Brown, D., Brooks, L. (Eds.) Career Choice and Development, San Francisco, CA.: Jossey-Bass, 167-261.

40. Westman, M., \& Etzion, D. L. (2005). The Crossover of Work-Family Conflict From One Spouse to the Other, Journal of Applied Social Psychology,35(9), 1936-1957. https://doi.org/10.1111/j.15591816.2005.tb02203.x

41. Westman, M., Etzion, D. \& Segev, K. (2002). The crossover of work-family conflict from one spouse to the other. Tel Aviv: Israel Institute of Business Research.

42. Warr, P. (2008). Work values: Some demographic and cultural correlates. Journal of Occupational and Organizational Psychology, 81(4), 751-775. https://doi.org/10.1348/096317907X263638 